\title{
THE BIOGRAPHICAL APPROACH IN THE ANALYSIS OF THE INDIVIDUAL AND SOCIAL ASPECTS OF BIOGRAPHICAL DISRUPTION
}

Summary of the Doctoral Thesis to obtain doctoral degree in social sciences

Speciality - Sociology

Riga, 2015 


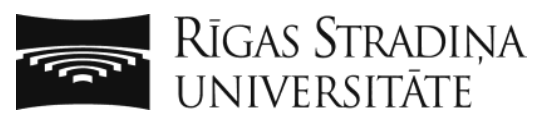

Maruta Pranka

\section{THE BIOGRAPHICAL APPROACH IN THE ANALYSIS OF THE INDIVIDUAL AND SOCIAL ASPECTS OF BIOGRAPHICAL DISRUPTION}

Summary of the Doctoral Thesis to obtain doctoral degree in social sciences

Speciality - sociology

Riga, 2014 


\section{The doctoral thesis was developed at Riga Stradiņš \\ University}

Scientific supervisor:

Dr. sc. soc. Associated Professor Ritma Rungule,

Riga Stradiņš University

Research consultant:

Dr. biol., Professor Edvīns Miklaševičs,

Riga Stradin̄š University

Official reviewers:

Dr. sc. soc, Assistant Professor Agita Lūse,

Rīga Stradin̄š University

Dr.sc.soc. Associated Professor Baiba Bela,

Latvia University

Dr. med. Associated Professor Anita Villeruša, Rīga Stradiņš University

The doctoral thesis will be defended on March 31, 2015 at 10.00 a.m. at the open meeting of the Riga Stradinšs University Sociology Dissertation Board in Auditorium Hippocrates, Dzirciema iela 16, Riga.

This doctoral thesis can be found in the Riga Stradiņš University library and on the Riga Stradiņš University webite: www.rsu.lv.

This doctoral thesis has been completed with financial support from the European Social Fund project "Support for doctoral study programmes and the receiving of scientific degrees at Riga Stradiņš University".
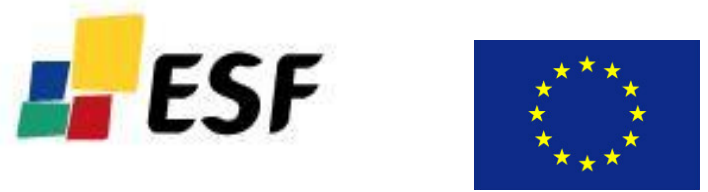

Dissertation board secretary: Dr. phil. in social work, Assistant Professor Signe Dobelniece 


\section{CONTENTS}

ABBREVIATIONS USED IN THE DOCTORAL THESIS $. . . \ldots \ldots \ldots \ldots . . .4$

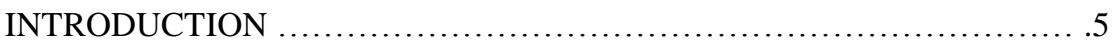

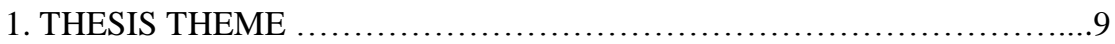

1.1. Topicality and scientific novelty of the Thesis theme ...............

1.2. Goal and tasks of the Thesis.................................. 11

1.3. Theoretical setting for the Thesis............................... 13

1.4. Methodology and sources for the empirical analysis................19

1.5. Structure of the Thesis......................................... 25

2. MAIN RESULTS AND CONCLUSIONS OF THE ANALYSIS ..........27

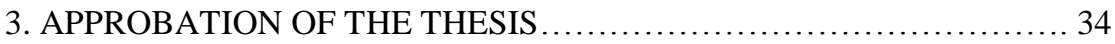

3.1. The author's publications regarding the THESIS theme $\ldots \ldots \ldots \ldots \ldots . . .34$

3.2. Reports and presentations at conferences and congresses........... 36

3.3. Published abstracts in collections of papers from conferences and

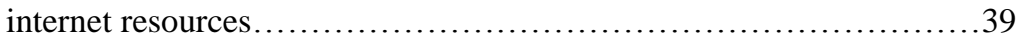

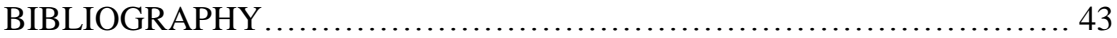




\section{ABBREVIATIONS USED IN THE DOCTORAL THESIS}

Brc breast cancer

V healthy

FSI Institute of Philosophy and Sociology

LU University of Latvia

Ov ovarian cancer

RSU Rīga Stradiņš University 


\section{INTRODUCTION}

In sociology, interest in the course of an individual's life is determined by one of the tasks of sociological research, namely, to find out the aspects, factors and elements that make up and influence the social essence of an individual. In course of life research, sociology focuses on both on the relationship between social changes and the biography as well as how the biography accommodates itself to a changing cultural and social environment during changing times; it also focuses on the meaning of rational choice as a defining factor in the dynamics of social positioning (Heinz \& Krüger 2001).

A biography is a story about the course of an individual's life, or, a life story, which includes not only a characterisation of the individual's sociodemographic situation and facts about his or her life; it also reflects the individual's subjective experience and interpretation of facts and events.

The concept of biographical disruption describes the influence of a significant, sudden event or events on the course of an individual's life that cardinally changes its direction and plans. Significant changes that affect an individual are experienced both objectively and also explained and interpreted subjectively in a person's biography.

The term "biographical disruption" was coined in 1982 by British sociologist Michael Bury to describe the experience of chronic illness and the way in which a life-threatening illness breaks an individual's social and cultural experience by threatening his or her self-identity. In analysing the experience of biographical disruption, Bury used Anthony Giddens' concept of "critical situation", which Giddens had applied to disruptions of a social nature, assuming that significant events in a person's biography had the same sort of influence (Giddens 1979). 
In this Thesis, the concept "biographical disruption" is interpreted as a process that includes significant changes in the course of an individual's life and his or her biography as well as his or her perception and interpretation of the course of his or her life. Biographical disruption is analysed as the process brought about by a "turning point" (Strauss 1959) or "fateful moment" (Giddens 1991) that is the basis for subsequent changes in a person's identity. Bury has studied the influence of chronic illness on significant changes in a biography and identity and concluded that chronic illness influences an individual's biography in the following ways:

1) habits and perception of life change;

2) the relationship between the ill person and those in his or her social network changes - some relationships are lost, others change;

3) resources - time, energy, finances, family, friends - must be mobilised (Bury 1982: 169).

The author of this thesis has used Giddens' concept of a "fateful moment" to expand on the content of the biographical disruption concept by stressing aspects of the individual's opportunities corresponding to the changed situation during fateful moments, when the individual, having involved the system of experts (various institutions, changes in lifestyle, etc.), may be presented with certain opportunities. The dissertation analyses the meaning of the participation of experts and emphasises the necessary quality aspects.

Fateful moments put in motion a process in which the individual may become completely different person. Fateful moments can potentially provide experience opportunities as well as develop self-identity and future action. Thus" consequential decisions, once taken, will reshape the reflexive project of identity through the lifestyle consequences which ensue" (Giddens 1991:143).

As the central concept of the thesis, biographical disruption is analysed as having been brought about by various causes. One of these causes is an inherited heightened risk of serious chronic illness - breast cancer or ovarian 
cancer - which the individual has due to a history of the illness in her family. The second cause for biographical disruption analysed is profound social changes due to historical events, namely, the Second World War and the Soviet occupation.

The individual and social aspects of biographical disruption have been analysed in their interaction, taking into account that every individual lives in a certain social time and social space and is a member of a certain social group or social stratum and a participant in certain social relationships. The individual aspects of a biographical disruption are linked to each individual's unique essence and experience and interpretation of his or her life. Individual experience, the individual's personality, the nature of his or her perception, his or her temperament and various other aspects of identity all play a role in the biographical disruption process that is introduced by a critical situation or fateful moment as well as in the overcoming of such a disruption.

The social aspects are associated with the individual's life in the social environment - a specific time and space, a specific group and social relationships, interpretations of events and changes included in the biography. As a historical and social agent, the individual accumulates the experience of his or her social group and social environment, which is layered/interacts with individual experience. In social interactions, individual experience is communicated to other members of society in the form of language, which is a social construct. The individual and social aspects of biographical disruption constantly interact and cannot be separated from each other. This means that a biographical disruption can be comprehended in depth and from many sides by analysing the individual's biography spanning his or her entire lifetime, in which the link between the individual and the social environment is constantly brought to the forefront.

The concept of biographical disruption describes a process in which significant, sudden events influence the course of an individual's life and 
radically change its direction and the individual's plans and dreams. These significant changes are experienced objectively, but they are also explained and interpreted subjectively in the individual's biography.

The doctoral thesis is based on an empirical study consisting of two parts. The empirical research data used for the Thesis study of serious chronic illness or heightened risk thereof as the cause of biographical disruption were obtained by the author when she worked on the interdisciplinary research project "Creation of a new interdisciplinary research team to investigate breast cancer and to increase the efficacy of therapy and the patient's quality of life" (agreement No. 2009/0230/1DP/1.1.1.2.0/09/APIA/VIAA/070) conducted in Oncology institute of Riga Stradiňš university.

For the study of biographical disruption due to radical social change, the author used empirical data from a longitudinal study performed by the National Oral History project of the Institute of Philosophy and Sociology at the University of Latvia. The Mãja (House) project has been conducted using a biographical approach over the course of many years, since 1996, in which life story interviews as well as personal documents (with narrators' permission) have been used as sources of information. 


\section{THESIS THEME}

\subsection{Topicality and scientific novelty of the Thesis theme}

Novelty of the research theme

1. This Thesis is the first in Latvia in which the process of biographical disruption and the individual and social aspects thereof have been analysed sociologically. The biographical disruptions analysed in the doctoral thesis are the result of various causes, which determine their different manifestations; however, several mutual, essential features have been identified during the analysis process. In addition to the three features defined by Michael Bury (transformation of identity, changed social relationships, the need for an expert's involvement), the Thesis author has added a fourth, namely, changes in the accessibility and use of the capital and resources available to the individual. Even though an individual's need for various resources increases during a biographical disruption, his or her accessibility to them as well as the use of his or her capital decreases or is lost altogether.

Alongside the identified mutual characteristic features, another aspect of the biographical disruptions analysed in the Thesis must also be emphasised, namely, that these disruptions have been influenced by the individual's belonging to a certain family. In the case of illness or the heightened risk of illness, it is the family through which the inherited breast cancer gene is passed down. Also in the case of biographical disruption due to social changes it is the family's belonging to a certain social stratum - the prosperous middle class that provokes repressions during a specific historical and social time and space.

2. The novelty is also related to the fact that the sociological aspects of genetically-inherited heightened risk of illness and genetically-inherited illness have not been studied before in Latvia. Studies of health and illness sociology 
and anthropology have been conducted in Latvia, but this dissertation is the first in Latvia about biographical disruption due to genetically-inherited heightened risk of illness. The empirical study performed and analysed in this thesis supplements the concept of illness as biographical disruption with the finding that biographical disruption and the identity changes involved with it can also be attributed to situations in which the biographical disruption is influenced by genetic heritage, in this case, a heightened risk of breast and/or ovarian cancer.

3. One of the most significant aspects of novelty is the innovation in research methodology. The biographical disruptions studied in the doctoral thesis, which are the result of various causes, have been analysed with the same methodological approach, namely, the biographical approach, in identifying mutual and different features of the process. This creates a methodological foundation for further sociological studies about the biographical disruption process, its individual and social aspects and also the possibilities of overcoming it, which can influence the well-being not only of the individual but of the whole community.

4. Another innovation in terms of methodology must also be mentioned, namely, the study of biographical disruption caused by social changes was conducted as a longitudinal, case study examining the processes of biographical disruption caused by radical social change. Such a study using the biographical approach and life stories as a methodology had not been done before in Latvia. In conducting a longitudinal case study, the biographical approach records an individual's personal experience in association with radical social transformations. 
Topicality of the research theme

Historical experience with radical social transformations and today's dynamic changes in the social sphere create a risk of biographical disruption in people's biographies. Biographical disruption can also be caused by critical situations of a personal nature during a person's lifetime, leading to a risk of stigmatisation for individuals as well as whole social groups. Knowledge of the process of biographical disruption (due to various causes), as well as the ways of overcoming it and identifying possibilities, can become a foundation upon which individuals can overcome a biographical disruption and facilitate their individual and social well-being.

The research is also topical in that, as new diagnostic possibilities emerge and technologies develop in the health care sphere, individuals are analysed in much detail, but insufficient attention is often paid to aspects of an individual's identity and the link between his or her life experience and health problems. By sociologically examining the process of biographical disruption

caused by an inherited cancer gene, the biomedical and social sciences may be brought nearer to each other in order to help individuals overcome biographical disruption due to health problems and identify necessary types of social support.

\subsection{Goal and tasks of the Thesis}

The goal of the Thesis is to perform a sociological study of the individual and social aspects of biographical disruption due to various causes in order to determine what individual and social factors facilitate successfully overcoming a biographical disruption.

\section{Tasks set out to achieve the goal}

1. Perform a theoretical analysis of the concept of biographical disruption based on previous studies done in the field of sociology. 
2. Study the features of biographical disruption by analysing theoretical sources and empirical research data.

3. Analyse the possibilities and compatibility of the biographical approach for the sociological study of the individual and social aspects of biographical disruption.

4. Analyse the social and individual aspects of biographical disruption using the biographical approach as a methodology.

5. Study biographical disruption caused by illness or heightened risk of illness by using data obtained from the empirical studies performed as part of the dissertation.

6. Study biographical disruption caused by radical social changes that have been identified by analysing data obtained from the empirical studies performed as part of the dissertation.

7. Analyse those individual and social factors that provide individuals with favourable conditions, facilitate a successful overcoming of biographical disruption and have been identified based on the theoretical and empirical data analysis performed as a part of the dissertation.

The object of the thesis is a biographical disruption during an individual's lifetime that is caused by individual and social factors.

The subject of the thesis is individual and social aspects of the experience of biographical disruption that has been caused by radical social changes and heightened risk of illness.

The research questions put forth in the thesis are:

1. What social and individual aspects are characteristic of the biographical disruption process? 
2. What are the most significant features of biographical disruption caused by various reasons?

3. What individual and social factors provide individuals with favourable conditions and facilitate a successful overcoming of biographical disruption?

\subsection{Theoretical setting for the Thesis}

In the thesis, biographical disruption is analysed as an event during an individual's lifetime that is provoked by radical changes, and a biography is considered to be a subjective reflection and interpretation of the course of a lifetime. On the one hand, a biography pertains to the social reality that influences the course of an individual's life. On the other hand, it pertains to those processes and events that a person wishes and is able to tell about, that is, his or her subjective experience and emotions.

In order to analyse the individual and social aspects of biographical disruption, the author of the doctoral thesis has used the biographical approach, because the individual biography is a reflection of the interaction between social development, social changes and processes, prevailing routine and custom, and the individual's experience. An individual's experience over a lifetime is formed by his or her relationships within the nearer microenvironment as well as his or her relationships that develop within the macroenvironment, that is, the individual's places and roles in various social structures that hold various levels of meaning in the individual's life.

In analysing biographical disruption, the thesis makes reference to the concept of "life trajectory" used in the sociological study of the course of a lifetime, which is the main concept in the biography theory developed by Fritz Schütze and is based on Anselm Strauss' "temporally ordered reciprocal permeation of social and subjective processes" (Schütze 1981). 
Strauss analysed biographical disruption as a process brought about by a "turning point" (Strauss 1959), stressing that the process of change is always put in motion by a single point, namely, the turning point. This turning point is initially identified as the critical event that provokes the person to admit that "I'm not the same as I was before, as I was used to being" and is accompanied by surprise, shock, bitterness, confusion, tension and/or a feeling of defeat in his or her experience of self (Strauss 1959: 95). Correspondingly to this situation, the individual searches for a new self "to fill the new experience with meaning and overcome the disruption brought about by this turning point that has led to a transformation of identity" (Boldt 2012: 99).

The term "biographical disruption" was coined in 1982 by British sociologist Michael Bury to describe the experience of chronic illness and the way in which a life-threatening illness breaks an individual's social and cultural experience by threatening his or her self-identity. In analysing the experience of biographical disruption, Bury used Anthony Giddens' concept of "critical situation" (Giddens 1979), which Giddens had applied to disruptions of a social nature, assuming that significant events in a person's biography had the same sort of influence.

Giddens' term "critical situation" has been used in the thesis's theoretical analysis to describe events that introduce significant changes in the life of an individual or group. His term "fateful moment" is used to describe "when individuals are called on to make decisions that are particularly consequential for their ambitions, or more generally for their future lives. Fateful moments are highly consequential for a person's destiny. Fateful moments are times when events come together in such a way that an individual stands, as it were, at a crossroads in his existence. There are, of course, fateful moments in the history of collectives as well as in the lives of individuals. They are phases at which things are wrenched out of joint, where a given state of affairs is suddenly altered by a few key events" (Giddens 1991: 112-113). For 
Giddens, the main element of fateful moments is that an individual considers/weighs the consequences of specific choices and actions and thereby becomes involved in the evaluation of risk. Fateful moments can potentially provide experience opportunities for how to use the consequences to develop one's self-identity and future actions. Thus, "consequential decisions, once taken, will reshape the reflexive project of identity through the lifestyle consequences which ensue" (Giddens 1991: 143).

Even though biographical disruption can be caused by various events and conditions and each individual experiences it differently, biographical disruptions nevertheless have mutual characteristic features:

1. Identity break or transformation, when the previous identity is interrupted and a new identity is created in its place that corresponds to the new situation, new individual feelings and also new external needs. This is a traumatic process, because it leads to a shocking awareness of the break between the past and the future.

2. Changes in social relationships take place; the changes taking place during the process of biographical disruption that affect the central actor in the process also apply to members of his or her closest social relationships. These members are either delegated new functions or they take up these new functions themselves by offering various types of social support. In some cases social relationships are terminated.

3. The need to mobilise resources in a situation of biographical disruption establishes the need to involve experts (good experts!).

4. Changes in the availability and use of capital and resources available to the individual. Even though the individual's need for various resources increases during biographical disruption, his or her access to such resources, as well as his or her use of individual capital, is decreased or even becomes impossible. 
By using Giddens' concept of fateful moments, the thesis expands the content of the biographical disruption concept by stressing aspects of an individual's opportunities corresponding to the changed situation at fateful moments, when the individual may be presented with opportunities through the involvement of the expert system (various institutions, changes in lifestyle, etc.). The thesis analyses the meaning of expert involvement, stressing the quality aspects of experts.

In addition to the concept of biographical disruption, the author of the thesis also analyses concepts put forth by other authors regarding the influence of significant, sudden events and their consequences on individual biographies by characterising similar manifestations of the processes but also including their differing contents and meanings. The concept of "turning point" as defined by Strauss is in effect close to the "epiphanies" in narratives formulated by Norman Denzin - moments that influence a person's life at its very foundation, that "structure a biographical or life study" (Denzin 1989: 70) and are existential crises. Also analysed are D. Mandelbaum's views, in which "turnings", or turning points, are attributed to any period in an individual's life when significant changes take place, including historical turning points, which actually should more precisely be called "historical markers", as well as the term "critical moments" used by Rachel Thomson in studies of disruption moments in the lives of young people (Thomson et al. 2007) and the concepts of "career break" and "social career" introduced by Robin Humphrey in biography studies (Humphrey 1993).

The thesis has examined the influence of the inherited breast cancer genes BRCA1 and BRCA2 on the development of biographical disruption. Illness and heightened risk of illness are characterised as mostly individual causes of biographical disruption. The influence of the inherited gene manifests itself as: 1) the individual's own illness,

2) heightened risk of becoming ill. 
In both situations the biographical disruption is a cumulative process that includes not only the actual event, namely, the illness or the receiving of information about the inherited gene. But the individual also has experience with the process and results of this illness within his or her close social relations, with whom he or she is genetically linked, that is, related by blood.

The second type of biographical disruption analysed in the thesis is associated with significant changes in all social systems, including culture, which is the most stable and inert system, based in traditions and collective identity. For this reason, biographical disruption due to social changes is analysed in conjunction with cultural trauma, during which changes take place on a macro-social level, directly or indirectly manifesting themselves at the individual level (Sztompka 2000).

The thesis author refers to interpretation of the concept of "capital" developed by Pierre Bourdieu. According to Bourdieu, capital is accumulated work; it is not only productively useful sums of money. Capital manifests itself in various forms in objective and subjective structures - as economic (material), symbolic, cultural and social capital - but these forms of capital are not equally available to and usable by all. Biographical disruption brings changes to the opportunities for using the capital available to an individual.

One of the instruments in the dissertation's analysis of biographical disruption is Bourdieu's concept of "habitus". He believes habitus is a set of dispositions in behaviour whose purpose is to maximise capital. The discovery and analysis of habitus has been especially important during times of rapid and radical social change, when the opportunity to reach and study habitus in action substantially increases. In times of social stability, when changes in society take place slowly, habitus remains indistinct and unseen. This indistinctness of habitus causes problems for researchers during biographical analysis. Because habitus is a part of personal identity, then the discovery and analysis thereof is of great importance in reaching research goals. 
Biographical disruption brings changes to the options an individual has to use the capital at his or her hand.

In studying and analysing the possibilities of overcoming a biographical disruption, the thesis concludes that this depends on the individual's own biographical work, or narrative reconstruction (Williams 2008), and various types of social support. The author of the thesis refers to A. Strauss, who, albeit writing about a heavy, long-term illness, describes biographical work as either returning to at least an approximation of one's previous life or restructuring one's life completely. Biographical work serves the actor's biography by including a review, preservation, repair and transformation of it (Corbin \& Strauss 1988: 70). According to the author of the dissertation, such a return to life through the process of biographical work can also be attributed to individuals who have experienced a biographical disruption due to social change.

During the process of biographic work performed in cases of biographical disruption due to various causes, the individual tries to connect his or her previous identity with the new identity that has arisen during the process if biographical disruption.

Various forms of social support, which facilitates a return to one's previous life or a coming to terms with one's new situation, play an important role in overcoming biographical disruption. The use and interpretation of the social support concept is becoming increasingly interdisciplinary in an attempt to see it in a cultural context and based on the link between social support and the structure of meaning created by culture (Jacobson 1987). In Western industrialised cultures, social support is linked with social integration, that is, understanding that social involvement always also means social support. Social support focuses on the interaction between individuals and encompasses emotional, instrumental, informative and evaluative support. In sociology, 
social support resources are considered to be derived from social networks. The task of social support is to amortize and decrease the negative influence on individuals of shocking, traumatic events by helping the individual to adapt socially. The availability of social support and the option to use various types of such support and resources are essential and meaningful factors not only for the health of the individual but also his or her well-being in general. A lack of social support can lead to social ostracising and social isolation.

\subsection{Methodology and sources for the empirical analysis}

The biographical approach has been used as a methodology for the thesis's sociological study of the individual and social aspects of biographical disruption (Chapter 2). The empirical analysis methodology (Chapter 3) has been developed using the scientific research experience of Catherine Riessman, Kathy Charmaz and Robert Miller.

The methodology of the empirical study is inductive; it leads from data collection in the empirical study to a theoretical analysis and the drafting of conclusions. In addition to the inductive methodology used in the empirical part of the thesis, the use of deduction is also significant, because a study of theoretical sources and previous studies has been conducted during the thesis

process. In drafting the biographical interview guidelines for both parts of the empirical study, analytical concepts from Bury, Giddens and other authors mentioned in the theoretical section were used.

Data-obtaining methods from the biographical approach (narratives encompassing the entire lifetime, called life stories, as well as biographical narratives focused on certain themes) were used for the sociological analysis of biographical disruption.

The methodological aspects of the biographical approach are associated with the type of narrative study. The biographical approach is used in narrative 
studies as the writing down and compiling of personal life experience as well as the use of autobiographical materials. In sociology, a personal narrative includes conversations of varying length and broader narratives about life, specific periods of one's life or specific issues. This approach is directed towards explaining the interaction between and subjective perception of the biography, history and social processes. At the same time, it must be stressed that personal experience includes social experience and the researcher focuses on specific individuals, in specific social places and at specific social times (Riessman 2008: 11).

The neorealistic approach is used in the analysis of biographical disruption (Roos 2003); this approach respects the characteristics of both the realistic and narrative approaches, taking into account that a life story is an interpretation of reality. From the realistic approach it has borrowed the view that individual opinions together reflect an objective reality, even though on a subjective level they may be partially incorrect. It must be noted that the realistic approach uses principles from grounded theory - a detailed and intensive data analysis in which phrases and sentences are commented and constantly compared, and data are coded in a detailed manner into thematic groups - whereas the methodology used in the thesis uses the principle found in the narrative approach in which narrative fragments are examined and analysed as units instead of fragmenting them into thematic categories.

From the narrative approach, the thesis has also acknowledged the meaning of context and the meaning of the specific character and uniqueness of the narrative. There are many theoretic approaches and types of narrative analysis: discourse, semiotic, linguistic, hermeneutic (Riessman 1993), thematic, structural, dialogue/performance and visual analysis (Riessman 2008). The thematic analysis principle has been used in the narrative study in thesis, and such an analysis stresses what is told, instead of how it is told, as the most important element of the narrative. 
In characterising the differences between thematic narrative analysis and grounded theory, the author of the thesis refers to Riessman's experience-based theoretic conclusions:

1) regarding the difference in the way the methods place prior concepts during the analysis process. If, in the early stages of a grounded-theory study, it avoids the prior concept, then a thematic analysis of a narrative searches for new theoretic discoveries during the data study process (without denying theoretical viewpoints) at the beginning of the study;

2) the most significant characteristic of a thematic analysis of a narrative is sequences - the preservation of the story and the richness of information included in the inherent sequence of the story;

3) unlike grounded theory, the narrative's place and time are important in a thematic analysis of a narrative, thereby giving the narrative a certain historicity;

4) as opposed to the word-for-word codification of grounded theory, the thematic analysis of a narrative is case-centered (Riessman 2008).

The study of theoretical sources during the thesis study process was integrated with the empirical study during fieldwork, during data processing and also during data analysis during the final stage, based on the empirical material obtained during interviews, thereby formulating the most significant analysis themes.

In addition to the narrative analysis, interview comments from researchers involved in the empirical study as well as personal document data and statistical data were used to characterise the context.

The data used for the thesis's empirical study of serious chronic illness or heightened risk thereof as a source of biographical disruption were obtained by the author when she worked on the interdisciplinary research project "Creation of a new interdisciplinary research team to investigate breast cancer 
and to increase the efficacy of therapy and the patient's quality of life" (agreement No. 2009/0230/1DP/1.1.1.2.0/09/APIA/VIAA/070).

The sociological study in the above-mentioned project included a quantitative questionnaire of breast cancer patients following a mastectomy $(\mathrm{n}=300)$ and in-depth biographical interviews $(\mathrm{n}=15)$ with women who were carriers of the inherited gene BRCA1 and/or BRCA2. The study and analysis of biographical disruption in the dissertation's empirical study uses in-depth biographical interviews that include questions about falling ill with breast cancer and heightened risk of breast cancer. By revealing a subjective reflection and interpretation of falling ill or having a heightened risk of illness, in-depth interviews and personal narratives show how women perceive inherited illness or heightened risk thereof and try to accept it, taking into account how it influences not only themselves but also subsequent generations.

The target group of the thesis empirical study consisted of persons with inherited breast cancer genes BRCA1 and/or BRCA2. The sample was created from the national database at the Oncology Institute of Rịga Stradiņš University, which contains histories of inherited breast cancer cases and the results of genetic tests for BRCA mutations.

The results and experience gained from the quantitative questionnaire performed as a part of the project were used to understand mutual problems and the development of biographical interview guidelines.

The selection of women included in the empirical study of the thesis consists of women who in the past four years have been identified as carriers of the inherited BRCA gene mutation. In order to have respondents from various socio-demographic strata as well as varying levels of general health, a focused selection of 24 women from the Oncology Institute's database was made, and these women were invited to an interview. Fifteen of the women agreed to the interview, and their parameters corresponded with the planned profile of the focus group. The selection included carriers of the inherited BRCA1 or BRCA2 
gene, four of whom were healthy, seven had had breast cancer, two had had ovarian cancer and two had had both ovarian and breast cancer. The youngest of the women was 26 years old during the study, and the oldest was 64 years old. The respondents were from various places in Latvia and had a variety of family and employment situations. Five of the respondents had close relatives who had been diagnosed with the BRCA1 or BRCA2 breast cancer gene. The remaining respondents had no information about the existence of inherited cancer genes among their close relatives because such tests had not been done. A socio-demographic characterisation of the respondents can be found in Attachment 1 of the thesis.

When interviewing both healthy and sick (treated) carriers of BRCA1 and BRCA2, an interpretation of the respondents' situations was revealed through personal narratives. The interview guidelines included the following themes: 1) previous experience and information about breast cancer and a characterisation of the family's experience; 2) people with whom the respondent discusses issues of illness, inherited genes and heightened risk of illness; 3) whether and how the respondent's personality, thinking and lifestyle had been influenced as a result of receiving information about inherited genes and heightened risk of illness; 4) a subjective explanation of the origin of the illness; 5) whether and how the respondent's social relationships had changed; 6) availability of various resources and opportunities to use the respondent's own individual capital; 7) how the respondent manages living with with the biographical disruption situation; 8) existing and necessary forms of social support (see interview guidelines in Attachment 2).

The interviews were performed based on the guidelines developed by the researchers; these guidelines cover as many of the problematic aspects of the study as possible, but the order of themes covered in the interviews was altered depending on the course of the conversation, just as the content of individual questions varied depending on the respondent's health status 
(whether she was healthy or had been ill). Collection of biographical data began with a partially structured interview in order to obtain the respondent's sociodemographic information, such as age, family status, type of employment and place of residence. This data was recorded in comments alongside the interview transcript. The interviews were conducted by researchers involved in the study, including the author of the thesis. Audio recordings of the interviews were made, and these recordings were later transcribed. Each transcription is supplemented with comments from the researchers that were made both during the interview and after it. The analysis of the narratives obtained from the interviews was performed based on the transcripts of the audio recordings, which are as precise a transfer in written form of the interviews as possible and reveal the course of the interview as well as the respondents' answers to the researchers' questions.

The realisation of the empirical study has been confirmed by the Ethics Committee of Rīga Stradiņš University. The results and experience obtained from the quantitative questionnaire administered as a part of the project have been used to comprehend mutual problems and to develop biographical guidelines.

Data from a longitudinal study conducted at the LU FSI National Oral History project were used in the study of biographical disruption caused by radical social changes. The Mãja (The House) project took place over the course of several years and used the biographical approach; as a source of information it used life story interviews, interviewee personal documents and also researchers' comments regarding the course and content of the interviews.

Empirical data and information used in the thesis:

- life story interviews with the owners of both buildings. Interviews with both owners were performed in several sessions, with new biographical events and aspects being revealed during each session;

- life story interviews with the residents of the buildings; 
- analysis materials from partially structured questionnaires that were initially responded to by the owners and residents of the buildings. This material includes the socio-demographic characterisation of the respondents, their answers to questions about changes in their living conditions and a characterisation of their current situations. Questions were posed based on a partially structured questionnaire (see Attachment 3), and answers were both written down and recorded in audio recordings;

- entries from the building's log book, which describes the composition and mobility of the building's residents;

- $\quad$ researchers' notes made during fieldwork;

- respondents' personal documents were also used, such as letters, correspondence with government institutions, photographs, diplomas, awards and materials from Latvian state archives to characterise and comprehend the context.

The interviews were performed by researchers of the LU FSI National Oral History project, including the author of the thesis. Transcripts of the biographical interviews were made. The names of respondents in the empirical study analysis have been changed in order to ensure their anonymity.

\subsection{Structure of the Thesis}

The thesis consists of an introduction, six chapters, a list of sources and three appendices.

The introduction justifies the choice of theme and describes its novelty, topicality and significance to sociology. The introduction states the goal of the study, its object, its subject and the goals set forth by the study. 
The first chapter analyses the theoretical aspects of biographical disruption. The chapter analyses the biography concept, describes the theoretical justification of the research study, provides an explanation of the concept of biographical disruption, characterises biographical disruption's place in a biography as the subjective interpretation of a lifetime and analyses significant approaches and concepts in the study of radical changes. The main characteristics of biographical disruption are analysed: a break or transformation of identity, when the previous identity is interrupted and a new identity is created that corresponds to the new situation; changes in social relationships and the need to procure resources, including experts; as well as changes in individual capital and the availability and use of resources. The chapter ends with a theoretical analysis of the development of biographical disruption from the perspective of chronic illness and radical social changes.

The second chapter in an effort to justify the choice of the biographical approach as a methodology in the thesis, contains a theoretical analysis of this approach. It discusses the context and essence of the biographical approach in sociology and examines its historical development. Further in the chapter, the focus moves to an analytical description of the narrative and life story as well as biographical study data analysis approaches. The theoretical chapter closes with an examination of the credibility aspects of personal data.

The third chapter describes the methodology used in the empirical study. Being that the thesis, analyses biographical disruption from a sociological perspective, based on the two separate parts of the empirical study, its methodological aspects are described in two separate sub-chapters. The chapter provides a characterisation and justification of data collection methods, research processes and context, selection of respondents and demography and also describes the data analysis methods and process.

The forth chapter describes the results of the empirical study by analysing the experience of biographical disruption of carriers of an inherited 
cancer gene. Corresponding to the approach of a thematic analysis of narratives focusing on specific issues and themes as well life story narratives, the main focus is on what has been said instead of how it is said; the context of the events included in the narrative is also taken into account. The interaction of the individual and social aspects of the biographical disruption process is also analysed, with specific types of biographical disruption and possibilities of overcoming them examined in separate sub-chapters.

The fifth chapter analyses the results of the empirical study regarding the influence of radical social changes on the biographical disruption process. It analyses the use of case study methods and the role of mediators in obtaining results from the study. The main focus of the chapter is on an analysis of the individual and social aspects of biographical disruption caused by social changes and ways of overcoming biographical disruption, namely, biographical work and the significance and opportunities of obtaining social support.

The conclusions chapter states the conclusions of the thesis, and responds to the main research questions posed by the study regarding the characteristic individual and social aspects of biographical disruption, the significant features of biographical disruption due to various causes and also summarises what individual and social factors create favourable conditions for individuals and facilitate the successful overcoming of biographical disruption.

The thesis comprises 193 pages. It has three appendixes. 240 sources are included in the list of sources.

\section{Main results and conclusions of the analysis}

A sociological analysis of the individual and social aspects of biographical disruption is conducted in the thesis, study. Conclusions have been drafted based on the results of the study. 
1. Biographical disruption is a broad concept encompassing individual and social aspects that describes a process introduced by a fateful moment and can be analysed in the context of a lifetime. Biographical disruption can by brought about by individual fateful moments of a personal nature as well as by radical social changes. However, any biographical disruption due to individual causes is nevertheless linked with social interaction throughout the whole individual's lifetime.

2. Biographical disruption consists of both individual and social aspects that interact with each other and cannot be separated from each other. The social aspects are associated with the individual's life in the social environment - a specific time and space - and the biography contains interpretations of events and changes. During the process of biographical work, individual experience is communicated to other members of society during social interactions in the form of language, which is a social construct. An individual's biography as an interpretation of the events over the course of a lifetime includes dimensions of chronological time and the experience of various levels of social relations because an individual represents a specific social group and time. The individual aspects of biographical disruption are associated with each individual's uniqueness, experience and interpretation of his or her lifetime. Individual experience, features of an individual's personality and perception, the individual's temperament and aspects of the individual's identity are manifested during the biographical disruption process brought about by critical situations or fateful moments.

3. Biographical disruption can be understood in a many-sided and indepth manner by analysing the individual's biography spanning his or her whole lifetime, in which we can identify the link between the social environment and the individual. The examination of biographical disruption is associated with the study of the family context. The biographical disruptions analysed in the thesis, are brought about by the individual's belonging to a 
specific family. This means belonging to a family with a certain genetic code that is the basis for a heightened risk of illness and/or belonging to a family that represents a certain social group that has suffered repressions during times of radical social change. An account of biographical disruption caused by social change shows the individual's link to large social transformations and historical changes.

4. Biographical disruption is a cumulative process of a traumatic nature; its main characteristics are identity transformation, changes in social relationships and the need for the involvement of experts and resources in order to overcome the disruption.

5. Characteristics common to biographical disruption due to various causes can manifest themselves in different ways. In the inherited gene cases studied in the thesis, which are manifested as heightened risk of illness and especially cases of actual illness, the importance of bodily identity and threats to such identity on the continuity of individual identity are emphasised. Individuals with a heightened risk of illness tend to have one of two attitudes towards their diagnoses: preparation and denial. Denial as a disallowing of the negative consequences and negative thoughts as well as a fear of positive genetic test results spares the emotions, but it is nevertheless an insufficient evaluation of the risk of illness. The positive aspect of learning one's genetic inheritance is an elevation of self-esteem through the process of identity transformation and heightened attention to health-promoting activities in order to lessen the risk of illness for oneself and other family members. Health care providers ought to emphasise these positive aspects and communicate them to individuals with heightened risk of illness. Biographical disruption due to radical social change takes place within the context of cultural trauma, because culture is a very inert, constant sphere consisting of traditions and values secured in collective memory and rooted in the continuity of social identity; it contains the individual's cultural identity complete with his or her awareness of 
values and social relationships. Radical social change leads to particularly traumatic consequences; traumatic changes at the macro-social level influence society at the macro level and influence groups functioning at the micro level as well as the course of each individual's life. Identity transformation brought about by social changes is associated with the forced change of various aspects of one's social identity in order to preserve one's existence as well as the different representation of one's identity in the private sphere as opposed to the public sphere.

6. In analysing changes in social relationships during the biographical disruption process, it is concluded that the self-esteem and values system of an individual affected or threatened by illness are influenced by changes in social relationships during a situation of illness or heightened risk of illness as well as by the involvement of members of these social relationships in social support measures. The analysis of the results of the study confirm the significant role of close, supportive relationships - especially from partners - in an individual's well-being, preservation of identity and his or her overcoming biographical disruption. In cases of biographical disruption due to radical social changes, both close and less close social relationships are violently severed. Survival strategy and the securing of one's existence is linked to the creation and preservation of social relationships after such a biographical disruption.

7. Biographical disruption can be overcome if the individual receives social support and performs biographical work, which is the individual's interpretive survey of the course of his or her lifetime within the interaction between its individual and social aspects.

8. The focus of attention on main themes and the explanation of biographical disruption during the process of biographical work are different depending on the cause of the biographical disruption. In the case of biographical disruption due to illness or the heightened risk of illness, the individual searches for and analyses the justification and causes of his or her 
genetic inheritance and illness (in both his or her individual experience and that of his or her family members as well as in his or her personal identity) during the biographical work process. The origin and cause of the illness are explained ambiguously; the origin of the illness is based not only on biomedical factors but also other factors, such as external or environmental, social, mental and mystified factors. In cases of radical social change, a justification for events is not sought; correspondents are very clear about the cause of the changes, namely, they are caused by the violence and injustice of the ruling powers. In their biographical work, the respondents tell about the suffering they and those close to them have endured and interpret their strategies and opportunities for survival.

9. The time aspect in biographical work is different depending on the cause of the biographical disruption. In cases of illness or heightened risk thereof, biographical work is performed simultaneously with the determination of the diagnosis and treatment of the illness. In the case of biographical disruption due to social changes, as analysed in the dissertation, biographical work is performed several decades after the event, once the political system in the country has changed. Individual biographical work is a part of a collective memory that has long been kept silent and has finally been given the chance to express itself. It is a part of the collective memories of the entire society in the context of cultural trauma.

10. The relationship between public and private space differs in the biographical disruption situations analysed in the thesis. In the case of biographical disruption due to illness and a heightened risk of illness, an individual's problems are addressed in both the private and public sphere through the involvement of consultants and specialists, participation in support groups and the use of various types of social networks. In the case of biographical disruption due to social changes, the private and public spheres are 
strictly separated from each other, and the positioning of identity also differs in the private and public spheres.

11. No matter the cause of biographical disruption, biographical work is healing in its attempt to unite the previous identity with the new identity that has emerged during the biographical disruption process. Biographical work contains an interpretation of the interaction between the individual and the social environment, thereby acknowledging that the individual and social aspects of biographical disruption are not mutually separable.

12. Biographical disruption establishes the need to involve experts and resources; at the same time, it also means a decrease or loss of available capital and the opportunities for using such capital. Social support of various kinds is very necessary in order to overcome biographical disruption; it facilitates a return to the previous life or the satisfactory adaptation of the individual to the new situation. In cases of biographical disruption, the most significant social support is given by members of the closest social relationships. Social support positively influences the preservation or reconstruction of identity and individual well-being as well as lessens the traumatic nature of the biographical disruption. Social support is also an important factor in averting the risk of the individual's marginalisation.

13. The content, need for and opportunities of receiving social support differ depending on the cause of the biographical disruption. In the case of biographical disruption analysed in the dissertation that were caused by social changes, social support is available in limited quantities and is provided only within the close circle of social relationships. For such individuals, searching for social support in the public sphere as well as any biographical work beyond one's closest social relationships involves a threat to their existence.

14. In the case of illness or heightened risk thereof, the individual can communicate about his or her issue and look for various types of social support on a much wider scale. If there is a deficit of social support provided by 
professional experts and health care specialists (support that covers informative, evaluative and emotional aspects), people look for mystified explanations and support. Such support, however, may provide inadequate social support that does not promote improvement of health. A need for experts who can provide professional and comprehensive social support is identified in the narratives.

15. In the case of biographical disruption due to illness in which the individuals receive their most significant social support from members of their closest social relationships (generally, the family), the social roles of the family members change and their emotional tension increases. A difficult and chronic illness can create biographical disruption not only for the patient but also for those persons close to him or her. Therefore, the whole family needs social support. As of yet, little research has been done in this area. In order for a person to accept and live with an illness or heightened risk of illness, respondents' strategies include the conviction that a healthy lifestyle, decreased stress and regular health check-ups avert the risk of falling ill and lengthen one's survival. 


\section{APPROBATION OF THE THESIS}

\subsection{The author's publications regarding the THESIS theme}

1. M. Pranka, A. Dzervite, R. Rungule, T. Lace, E. Miklasevics, J. Gardovskis (2014). Assessment of life quality factors by breast cancer patients. SHS Web conferences, Vol. 10. Published online: 9 September 2014. DOI: http://dx.doi.org/10.1051/shsconf/20141000034; HS Web of Conferences, Vol. 10, 2014, $4^{\text {th }}$ International Interdisciplinary Scientific Conference "Society, Health, Welfare".

2. M. Pranka (2013). We did not tell anything to the strangers. Communication between private and Soviet public space. In: Oral History:Dialogue with Society/Mutvārdu vēsture: Dialogs ar sabiedrību. Red. I. Garda-Rozenberga. Rīga: LU FSI; Latvijas Mutvārdu vēstures pētnieku asociācija "Dzīvesstāsts", 188.-194. lpp.

3. M. Pranka (2012). Biogrāfiskais pārrāvums kā pieredze dzīves gājumā. Chapter in collective monography Dzīvesstāsts un pašapzinga. Mutvārdu vēsture Latvijā. Rīga: LU FSI; Latvijas Mutvārdu vēstures pētnieku asociācija "Dzīvesstāsts", 58.-71. lpp.

4. Dzervite, M. Pranka, T. Lāce, R. Rungule, J. Gardovskis, E. Miklasevics (2013). Initial findings of breast cancer risk factors from a survey conducted at Pauls Stradins Clinical University Hospital. Acta Chirurgica Latviensis (RSU), 13, pp. 34-37.

5. Dzervite, M. Pranka, A. Irmejs, J. Gardovskis, E. Miklasevics (2012). Overcoming potential suffering: Interpreting the diagnosis of hereditary ovarian and breast cancer at the Riga Stradins University Oncology Institute. Avalable: http://www.inter-disciplinary.net/probing-theboundaries/wp-content/uploads/2012/10/dzervitesufpaper.pdf; in conference website: http://www.inter-disciplinary.net/probing-the- 
boundaries/making-sense-of/suffering/project-archives/conferenceprogramme-papers-and-abstracts/session-2-adaptations/

6. M. Pranka (2011). Biogrāfiskās pieejas iespējas migrācijas izpētē. No: Kultūras identitātes dimensijas. Ed.. S. Krūmiņa-Koņkova. Rīga: LU FSI, 169.-187.

7. M.Pranka (2010). Individuālās biogrāfijas kā sociālās izziṇas resurss laikmeta procesu pētniecībā. In: RSU Zinātniskie raksti 2010. Ed. A. Lapsa. Rīga: RSU, 129.-136. lpp.

8. M. Pranka (2010). Migration as loss of home". In: Oral History: Migration and Local Identity: Online proceedings of papers presented at the Conference at the University of Latvia in Riga, June 27-29, 2008, pp. 222-231.

9. M. Pranka (2010). Значение биографических исследований в период социально-экономического кризиса. In: Partnerstwo i wspolpraca a kryzys gospodarczo-spoleczny w Europie Šrokowej i Wschodniej, t. 2, pod redakcja S. Prtyckiego. Lublin: Katolicki Uniwersitet Lubelski Jana Pawla II, Wydawnictwo KUL, s. 785-791. 10. M. Pranka (2010). Methodological approach aspects in researching social processes and situation of children in risk. In: Collection of Scientific Papers 2009. Rīga: RSU, pp. 216-219

11. M. Pranka (2009). Biographical approach in researh of social processes in a case study. In: Proceedings of the International Conference "Risk Society: Challenges for the 21st Century", Athens, 2009. Accepted for publication.

12. M. Pranka (2009). Migratsioon versus kodu: vaateid ühele uurimisprojektile. In: Maetagused, 43. Red. Koiva and A. Kuperjanov. Tartu, 2009, pp. 85-104 
13. M. Pranka (2008). Biogrāfiskā pieeja sociālo procesu vērtējumā. In: Letonika. Otrais kongress. Nacionālā mutvārdu vēsture. Religiskāas idejas Latvijā, 2. grām. Rīga, FSI, 2008, 127.-135. pp.

14. M. Pranka. Identitāte reǵionālās attīstības kontekstā. In: Dzīvesstāsti: vēsture, kultūra, sabiedrība. Rīga: LU FSI; NMV, 2007, 350.-354. pp.

\subsection{Reports and presentations at conferences and congresses}

1. M. Pranka, "Migration as Biographical Disruption" (2014), report in the 5th International Symposium of the Finnish Oral History Network „Travelling Memories: Lives in Transition”, November 27-28, 2014, Helsinki.

2. M. Pranka, E. Miklaševičs, L. Līvmane (2014). "Attieksme pret krūts un olnīcu vēža profilaktiskajām apskatēm un to ietekmējošie faktori. Sociologiskās aptaujas rezultāti”. RSU Scientific conference, 10.11.2014. Rīga.

3. M. Pranka (2013). "Biogrāfiskais lūzums: kultūras trauma dzīvesstāstos". The $5^{\text {th }}$ Letonikas Congress, 28-30. 10.2013. Rīga.

4. M. Pranka, A. Dzērvīte, R. Rungule, J. Gardovskis, E. Miklaševičs (2013). "Risk of hereditary dreast cancer as biographical disruption:". 13th conference of the European Sociological Association "Crisis, Critique and Change", 28-31.08.2013. Turin, Italy.

5. M. Pranka (2013). "Experience of biographical disruption. Consequences and risks". $13^{\text {th }}$ conference of the European Sociological Association "Crisis, Critique and Change", 28.-31.08.2013. Turin, Italy. 
6. M. Pranka (2012). "Slimība kā dzīves pagrieziena punkts. Subjektīvais vērtējums" (Illness as life's turning point. subjective evaluation). 26th Conference of the Nordic Sociological Association Trust and Social Change) 15.-18.augustā Reikjavik, Iceland.

7. M. Pranka (2012). "Biogrāfiskā pieeja daudzdisciplinārā pētījumā" (Biographical approach in multidisciplinary research). International scientific conference "Humanities and Contemporary World", June, 2012, Podgorica, Montenegro.

8. M. Pranka (2012). "Biogrāfiskais pārrāvums kā pieredze dzīves gājumā". The $15^{\text {th }}$ International scientific conference "Sabiedrība un kultūra: Mainīgais un nemain̄̄gais cikliskumā”, may, 2012, Liepāja, Latvia.

9. M. Pranka (2012). "Biogrāfiskais lūzums un tā komunikācija padomju telpā”. International scientific conference "Mutvārdu vēsture: Dialogs ar sabiedrību", 2012, marts. Rīga.

10. M. Pranka (2011). "Identitāte migrācijas krustcelēs" (Identity in the Crossroads of Migration). The 10th conference of the European Sociological Association "Social Relations in Turbulent Times", September, 2011, september. Geneve, Switzerland.

11. M. Pranka, A. Dzērvīte, T. Lāce, R. Rungule, A. Irmejs (2011). "Sociological dimensions in breast cancer multidisciplinary research". The 10th conference of the European Sociological Association "Social Relations in Turbulent Times", September, 2011, september. Geneve, Switzerland.

12. M. Pranka (2011). "Migrācijas procesi un sieviešu dzives trajektorijas". The $15^{\text {th }}$ International scientific conference "Sabiedriba un kultūra: Robežas un jauni apvāršņi”, May, 2011, Liepāja, Latvia.

13. M. Pranka (2010). "Refleksijas par biogrāfiskiem pētījumiem, pētot sociālos un telpas procesus Latvijâ". (Reflection on the biographical 
study in researching social and spatial processes in Latvia). International scientific conference "Applied Biographical Research / Anwendungsbezüge der Biographieforschung”, September, 2010, Nirnberg, Germany

14. M. Pranka (2010). "Biogrāfisko pētījumu nozīmība sociālekonomiskās krīzes periodā" (The relevance of biographical researches in the period of socio-economical crisis). International scientific conference "Partnership and Cooperation in the Period of Socio-Economical Crisis in Central and Eastern European Countries", May, 2010, maijs. Nalencevo, Poland.

15. M. Pranka (2010). "Biogrāfiskā pieeja socioloǵijā - teorijas un prakses paradokss”. The $13^{\text {th }}$ International scientific conference „Sabiedrība un kultūra: Haoss un harmonija", April, 2010, Liepāja, Latvia.

16. M. Pranka (2010). Methodological aspects of use life history research for investigation social processes. International scientific conference "Oral History and Fieldwork. The (Re)uses and Interpretation of Research Materials", December, 2010, Helsinki, Finland.

17. M. Pranka (2011). “Mēs svešiem neko nestāstījām. Par identitāti privātajā un padomju publiskajā telpā”. Apvienotais III Pasaules latviešu zinātnieku kongress un IV Letonikas kongress, October, 2011, Rīga.

18. M. Pranka (2010). "Biogrāfisko pētījumu izmantojums sociologiskā izpētē”. Rīgas Stradinš̌ University scientific conference, 2010. Rīga.

19. M. Pranka (2009). "Biogrāfiskā pieeja sociālo procesu izpētē". International scientific conference "Risk Society: Challenges for the $21^{\text {st }}$ Century", november, 2000, Athens, Greece.

20. M. Pranka (2009). "No atmiņām uz sociālo procesu izziņu. Gadījuma analīze“. International scientific conference "Lithuanian Euro- 
integration, National Identity, and Collective Historical Memory", November, 2009, Vilnius, Lithuania..

21. M. Pranka (2009). "Dzīvesstāsti kā izzinanas avots un pētījuma metode". International scientific conference "Sociālā darba perspektīvas un iespējas mūsdien̄̄gā Eiropā̄, 2009, marts. Rīga.

22. M. Pranka (2008). "Migrācijas procesu analīze biogrāfiskā pētījumā”". International scientific conference "Society, Health, Welfare", November 2008, Rīga.

23. M. Pranka (2008). "Migration versus home". International scientific conference "Oral History: Migration and Local Identities" June, 2008, Rìga.

24. M. Pranka (2007). "Biogrāfiskā pieeja sociālo procesu vērtējumā". Letonika’s congress. Rīga.

25. M. Pranka (2007). "Mūsu dzīves telpa. Biogrāfiskās metodes iespējas vides pētniecībā". The $8^{\text {th }}$ conference of the European Sociological Association, September, 2007, Glasgov, UK.

\subsection{Published abstracts in collections of papers from conferences and Internet resources}

1. M. Pranka, Migration as Biographical Disruption, tēzes referātam Somijas mutvārdu vēstures tīklojuma 5.starptautiskajā simpozijā „Travelling Memories: Lives in Transition”. Helsinki, 2014

2. M. Pranka, E. Miklaševičs, L. Līvmane. Attieksme pret krūts un olnīcu vēža profilaktiskajām apskatēm un to ietekmējošie faktori. Sociologiskās aptaujas rezultāti. Tēzes. RSU 2014. g. zinātniskā konference. Rīga, 2014, 276. lpp.

3. M. Pranka, A. Dzērvīte, R. Rungule, J. Gardovskis, E. Miklaševičs. Risk of hereditary breast cancer as biographical disruption. Tēzes 
referātam Eiropas Sociologu asociācijas (ESA) 13. zinātniskajā konferencē „Crisis, Critique and Change”, 28.-31.08.2013. Turīnas Universitātē, Itālijā.

4. M. Pranka. Experience of biographical disruption. Consequences and risks. Tēzes referātam Eiropas Sociologu asociācijas (ESA) 13. zinātniskajā konferencē "Crisis, Critique and Change", 28.-31.08.2013. Turīnas Universitātē, Itālijā.

5. M. Pranka, A. Dzērvīte, J. Gardovskis, E. Miklaševičs "Slimība kā dzīves pagrieziena punkts. Subjektīvais vērtējums" (Illness as life's turning point. Subjective evaluation). Tēzes referātam Ziemel̦valstu Sociologijas asociācijas 26. konferencē "Trust and Social Change", 2012, augusts. Reikjavīka, Īslande.

6. R. Rungule, M. Pranka, T. Lāce, A. Dzērvīte, E. Miklaševičs. "Biographical experience of women with cancer". Tēzes referātam Starptautiskās sociologu asociācijas Pasaules sociologu 2. forumā 1.-4.08.2012. Buenosairesa, Argentīna;

https://isaconf.confex.com/isaconf/forum2012/webprogram/Paper27445. html

7. M. Pranka. "Septiņdesmito gadu jauniešu socioloǵiskā pieredze”. Tēzes referātam starptautiskā konferencē "Jaunatne Latvijā, Eiropā, pasaulē: iespējas un riski”, 2012, jūnijs. Rīga.

8. M. Pranka, "Biographical break and its communication in the Soviet space". Tēzes referātam starptautiskā konferencē "Mutvārdu vēsture: dialogs ar sabiedrību" (Oral History: Dialog with Society), 2012, marts. Rīga.

9. M. Pranka, A. Dzērvīte, J. Gardovskis, E. Miklaševičs. "Sociologiisko rādītāju atšķirības par 65 gadiem jaunākām un vecākām krūts vēža slimniecēm”. Tēzes. RSU 2012. g. zinātniskā konference. Rīga, 2012. 
10. M. Pranka, A. Dzērvīte, T. Lāce, R. Rungule, A. Irmejs. "Sociological dimensions in breast cancer multidisciplinary research". Tēzes referātam Eiropas Sociologu asociācijas (ESA) 10. konferencē "Sociālās attiecības trauksmainā laikā" (European Sociological Association, $10^{\text {th }}$ conference "Social Relations in Turbulent Times"). 2011, septembris. Ženēva.

11. M. Pranka. "Identity in the Crossroads of Migration". Tēzes referātam Eiropas Sociologu asociācijas (ESA) 10. konferencē "Sociālās attiecības trauksmainā laikā" (European Sociological Association, 10th conference "Social Relations in Turbulent Times"). 2011, septembris. Ženēva.

12. M. Pranka, A. Dzērvīte, T. Lāce, R. Rungule, E. Miklaševičs, J. Gardovskis. "Dz̄ives kvalitātes mērījumi krūts vēža slimniecēm P. Stradiṇa Klīniskajā universitātes slimnīcā”. Tēzes. RSU 2011. g. zinātniskā konference. Rīga, 2011.

13. M. Pranka, A. Dzērvīte, T. Lāce, R. Rungule, E. Miklaševičs, J. Gardovskis. "Sociologisko aspektu izpēte krūts vēža pētījumā". Tēzes. RSU 2011.g. zinātniskā konference. Rīga, 2011.

14. M. Pranka. "Biographical knowledge as professional competence in researching society”. Tēzes starptautiskā konferencē „Rehabilitation Days". Rīga, 2010.

15. Dzērvīte, M. Pranka. "Dzīves kvalitātes mērījumu izmantošana pētījumā par krūts vēža klīnisko, morfoloǵisko un molekulāro īpatnību korelāciju izpēti dzīves kvalitātes uzlabošanai”. Tēzes. RSU 2010. g. zinātniskā konference, 2010, marts. Rīga.

16. M. Pranka. "Biogrāfisko pētījumu izmantojums sociologískā izpētē”. Tēzes. RSU 2010. g. zinātniskā konference, 2010, marts. Rīga. 
17. M. Pranka. "From memories to inquiring the social processes: case study analysis". Tēzes starptautiskā konferencē "Lithuanian EuroIntegration, National Identity, and Collective Historical Memory”, 2009, novembris. Viḷna.

18. M. Pranka. "Migration: the opposite of home: a case study", starptautiska konference "Mutvārdu vēsture: migrācija un lokālā identitāte” („Oral History: Migration and Local Identity”), 2008, jūnijs. Rīga. 


\section{BIBLIOGRAPHY}

1. Boldt, T. D. (2012). Migration biography and ethnic identity: on the discontinuity of biographical experince and how tuning points affect the ethnicisation of identity. In: Hackstaff, K., Kupferberg, F., and Negroni, C. (eds.). Biography and Turning Points in Europa and America. University of Bristol, UK: The Policy Press, pp. 93-124.

2.Bourdieu, P. (1986). The forms of capital. In: Richardson, J. G. (ed.). Handbook of Theory and Research for the Sociology of Education. New York: Greenwood Press, pp. 241-258.

3. Bury, M. (1982) Chronic illness as biographical disruption. Sociology of Health and Illness, Vol. 4, No. 2, pp. 167-182.

4.Chamberlayne, P., Bornat, J. and Wengraf, T. (eds.). (2000). The Turn to Biographical Methods in Social Science: Comparative Issues and Examples. London: Routledge.

5. Charmaz, K. (1995). The body, identity, and self: Adapting to impairment. The Sociological Quarterly, Vol. 36, pp. 657-680.

6. Charmaz, K. (2002). Stories and silences: disclosures and self in chronic illness. Qualitative Inquiry, Vol. 8, No 3. pp. 302-327.

7. Corbin, J. M. and Strauss, A. L. (1987). Accomplishments of chronic illness: Changes in body, self, biography, and biographical time. In: Roth, J. A. and Conrad, P. (eds.). Research in the Sociology of Health Care, vol. 6: The Experience and Management of Chronic Illness. Greenwich: J.A.I. Press, pp. 249-281.

8. Denzin, N. K. (1990). Interpretive Interactionism. Newbury Park, CA: Sage Publications.

9. Giddens, A. (1979). Central Problems in Social Theory. London: Macmillan; Berkeley: University of California Press.

10. Giddens, A. (1991a). Modernity and Self-identity: Self and Society in the Late Modern Age. Stanford: Stanford University Press.

11. Glaser, B. and Strauss, A. L. (1968). Time for Dying. Chicago: Aldine.

12. Heinz, W.R. and Krüger, H. (2001). Life course: innovations and challenges for social research. Current Sociology, Vol. 49, No. 2, pp. 29-45.

13. Lūse, A. (2007). Patības balss un cēlonssakarību atbalss sižetos par krīzes pieredzi. No: Dzīvesstāsti: vēsture, kultūra, sabiedrība. Rīga: LU FSI NMV, 269.-283. lpp.

14. Mathieson, C. M. and Stam, H. J. (1995). Renegotiating identity: cancer narratives. Sociology of Health \& Illness, Vol. 17, No. 3, pp. 282-306.

15. Mežinska, S. (2010). Hroniskas slimības subjektīvā pieredze un pensijas vecuma cilvēku dzīves kvalitāte. Promocijas darbs socioloǵijas nozarē. Rīga: RSU. SAGE.

16. Miller, R.L. (2000) Researching Life Stories and Family Histories. London:

17. Pranka, M. (2009). Migratsioon versus kodu: vaateid ühele uurimisprojektile. Mäetagused: An electronic journal of folklore, Vol. 43, pp. 85-104.

18. Pranka, M. (2012). "Biogrāfiskais pārrāvums kā pieredze dzīves gājumā̄", nodaļa kolektīvajā monogrāfijā Mutvārdu vēsture: dzīvesstāsts un pašapzinga. Red. I. Garda-Rozenberga. Rīga: LU FSI, 58.-71. lpp.

19. Riessman, C. K. (2002). Illness Narratives: Positioned Identities: invited annual lecture. Cardiff, Wales: Health Communication Research Centre, Cardiff 
University.

20. Riessman, C. K., (2008) Narrative Methods for the Human Sciences. SAGE Publications.

21. Roos, J. P. (2003). Context, authentity, referentiality, reflexivity: back to basics of autobiography. In: Humphrey, R., Miller, R., Zdravomyslova, E. (eds.). Biographical Research in Eastern Europe: Altered Live and Broken Biographies. London: Ahgate, pp. 27-38.

22. Skultāne, V. (2002). Naratīvs un slimība. No: Lūse, A. (sast.). Cilvēks. Dzīve. Stāstījums. Rīga: Latvijas Antropologu biedrība, 13.-22. lpp.

23. Skultāne, V. (2001). Liktenis un biogrāfiju veidošana. No: Zirnīte, M. (sast.). Spogulis: Latvijas mutvārdu vēsture. Rīga: LU FSI, NMV, 46.-70. 1pp.

24. Skultans, V. (1998). The Testimony of Lives: Narrative and Memory in Post-Soviet Latvia. London; New York: Routledge.

25. Skultans, V. (1999). Narratives of the body and history: illness in judgment on the Soviet past. Sociology of Health and Illness, Vol. 21, No. 3, pp. 310-328.

26. Skultans, V.S. (2001). A historical disorder: neurasthenia and the testimony of lives. In: Bhurga, D. and Littlewood, R. (eds.). Colonialism and Psychiatry. Delhi: Oxford University Press, pp. 244-264.

27. Skultans, V. (2002). Editorial: Narrative, illness and the body. Anthropology and Medicine, Vol. 7, No. 1, pp. 5-13.

28. Sztompka, P. (2000). Cultural Trauma. The other face of social change. European Journal of Social Theory, Vol. 3 